\title{
Circulating Oxidized Low Density Lipoprotein and Non-High Density Lipoprotein Cholesterol Concentrations in Metabolic Syndrome Egyptian Women Before and After Specific Nutritional Therapy
}

\author{
Maha I. A. Moaty*, Salwa M. El Shebini, Magda S. Mohamed, Nihad H. A. El-Arabi, Salwa T. Tapozada, Laila M. Hanna \\ National Research Center - Food Science and Nutrition, Cairo, Egypt
}

Citation: Moaty MIA, El Shebini SM, Mohamed
MS, EI-Arabi NHA, Tapozada ST, Hanna LM.
Circulating Oxidized Low Density Lipoprotein and
Non-High Density Lipoprotein Cholesterol
Concentrations in Metabolic Syndrome Egyptian
Women Before and After Specific Nutritional
Therapy. Maced J Med Sci. 2012 Jul 31;5(2):147-
151. http://dx.doi.org/10.3889/MJMS.1957-
5773.2012 .0230$.
Key words: metabolic syndrome; obesity; oxidized
LDL; non-HDL-C; tigernut.
Correspondence: Maha I. A. Moaty. Food
Science and Nutrition Department, National
Research Center, El Bohoth Street, El Dokki,
Cairo, Egypt. Phone: 0020201006388792. Email:
ibrahim.maha@yahoo.com
Received: $10-J a n-2012 ;$ Revised: 19-Feb-2012;
Accepted: $13-M a r-2012 ;$ Online first: 03-Jul-2012
Copyright: @ 2012 Moaty MIA. This is an open
access article distributed under the terms of the
Creative Commons Attribution License, which
permits unrestricted use, distribution, and
reproduction in any medium, provided the original
author and source are credited.
Competing Interests: Theauthors have declared

that no competing interests exist.

\section{Abstract}

Aim: To investigate the relation between the metabolic syndrome (MetS), and oxidized low density lipoprotein (ox-LDL) and non-high density lipoprotein cholesterol (non-HDL-C), and to evaluate a dietary therapy composed of a balanced hypocaloric regimen plus a supplement prepared from whole wheat and tigernut flour (Cyperus Esculentus).

Material and Methods: Forty two obese Egyptian female volunteers (their mean age was $47.76 \pm 0.90$ ) were given a low caloric balanced diet (900-1000 kcal) for 4 weeks, and then the supplement was used to replace Baladi bread during the next four weeks. The metabolic syndrome was diagnosed according to the International Diabetes Federation criteria.

Results: The prevalence rate of MetS was found to be $76.2 \%$. The metabolic syndrome was significantly associated with higher levels of total cholesterol (T.cholesterol), LDL-C, ox-LDL and non HDL-C. Significant and sustained reduction in the levels of fasting blood glucose and $\mathrm{HbA1c}$, normalization of lipid profile, and decrease in the levels of ox-LDL were observed after the end of the two periods of the dietary therapy.

Conclusion: Metabolic syndrome is associated with higher levels of circulating ox-LDL and non-HDLC. The use of the dietary therapy composed of balanced hypocaloric regimen plus a supplement rich in antioxidants and anti-inflammatory components, reduced obesity and the risky biochemical markers of the MetS.

\section{Introduction}

The metabolic syndrome is a common and complex disorder combining obesity, dyslipidemia, hypertension and insulin resistance [1]. It is a primary risk factor for diabetes and cardiovascular disease [2].

Obesity may induce systemic reactive oxygen species (ROS), and in turn is associated with an irregular production of adipokines that contribute to the development of the metabolic syndrome [3]. Another emerging risk factor for the development of Met $S$ is oxidized LDL (ox-LDL), which activates circulating monocytes, thereby increasing their ability to infiltrate the vascular wall. This increased infiltration is a primary stage in atherogenesis [4], which were associated with increased risk of future myocardial infarction, even after adjustment of LDL-C and other established cardiovascular risk factors [5].

Recent data suggest that increased oxidative 
stress in adipose tissue is an early instigator of the metabolic syndrome and that the redox state in adipose tissue is a potentially useful therapeutic target for the obesity-associated metabolic syndrome [6].

The hallmark of atherogenic dyslipidaemia is low levels of high-density lipoprotein cholesterol (HDLC) as well as elevated triglyceride (TG) levels, while low density lipoprotein cholesterol (LDL-C) may be marginally elevated in this setting [7]. A single apolipoprotein B100 (apo B) molecule is present in all major atherogenic particles of liver origin [very low and intermediate density lipoprotein (VLD and IDL)], and LDL. Therefore, measurement of Apo B provides direct information on the number of atherogenic particles (LDL and non LDL), irrespective of their size. Further, these atherogenic particles, collectively known as non-HDL lipoproteins, are associated with atherogenic dyslipidaemia, insulin resistance, portal hyperinsulinemia and metabolic syndrome $[8,9]$.

A research showed that a diet high in fat and carbohydrates induces a significant increase in oxidative stress (OS) and inflammation in persons with obesity [10]. Weight loss through nutritional and pharmacological treatment in addition to supplementation with antioxidant nutrients such as vitamins E, A and C, and flavonoid, among others, may be the key to the risk of developing other pathologies related to OS [11]. Nuts and whole cereal grains are rich sources of vitamins, minerals, antioxidants, phytosterols and plant protein which could be beneficial in such conditions. Botanical omega-3 fatty acid (alphalinolenic acid/ALA) has been shown to alleviate the prothrombotic and proinflammatory profile of the metabolic syndrome $[12,13]$. Nuts especially tigernut has a high content of oleic acid that has a positive effect on LDL-C oxidation, thereby preventing heart attacks and thrombosis [14].

Our aim was to investigate the relation between the metabolic syndrome, and both of ox-LDL and nonHDL-C. We also studied the effect of certain diets that lower metabolic syndrome factors, and the levels of oxLDL and non-HDL-C in a sample of Egyptian obese volunteers.

\section{Materials and Methods}

\section{Materials}

A formula that was designed in this study prepared from whole wheat (30\%), tiger nut flour (40\%), plus sesame seeds (10\%), flax oil (10\%), skimmed milk (5\%) and flavor. The tiger nut was purchased from the local market, cleaned and dried at low temperature (40 ${ }^{\circ} \mathrm{C}$ ) and then grind in powder form. Vanilla was added as a flavor. The formula was prepared as cookies each weighing about $20 \mathrm{~g}$.

\section{Chemical analysis of the supplement}

The macronutrient contents of the baked cookies including protein, carbohydrates and total fat were estimated [15]. Dietary fiber determination was done [16]. The mineral contents of the sample were extracted by ashing the dried sample in hot oven at $500^{\circ} \mathrm{C}$ for 24 hours, then dissolved by few drops of concentrated hydrochloric acid, and the volume completed to $25 \mathrm{ml}$ with de-ionized water. The mineral contents were measured by a Varian Model Spectra AA220, Flame Atomic Absorption Spectrophotometer, with an airacetylene and hollow cathode lamps run under the conditions recommended by the manufacturer (Varian Australia Pty., Ltd., Musgrave, Vic.3171, and Australia). The wavelength, slit width and burner height were adjusted according to suitable conventional values [17]. Fatty acids extraction was carried by the petroleum ether extract of different plant materials according to AOAC (2000) [18], then subjected to gas-liquid chromatography (GLC) analysis of fatty acids using Helwett Packard: HP 6890-GC. Total polyphenols were determined according to Adekanmiet. al., 2009 [19] (Table 1 \& Figure 1).

\section{Subjects}

This study was conducted on a group of 42 obese Egyptian female volunteers; their age range was 36-54 years with a mean of $47.76 \pm 0.90$. The protocol of the study was approved by the National Research Center Ethics Committee. In addition an informed consent was obtained from each participant to be included in the study. All the included females were evaluated by standard physical examination and routine clinical laboratory tests. They were divided into two groups after the basal clinical and biochemical investigations:

Group (1) 32 women who fulfilled at least three of the following five criteria denoting Met $\mathrm{S}$ according to International Diabetes Federation, 2010 [20]:

1. Elevated waist circumference: Equal to or greater than $80 \mathrm{~cm}$.

2. Elevated blood pressure: Equal to or greater than $130 / 85 \mathrm{~mm} \mathrm{Hg}$ or use of medication for hypertension. 
3. Elevated serum triglycerides: Equal to or greater than $150 \mathrm{mg} / \mathrm{dl}$. $50 \mathrm{mg} / \mathrm{dl}$.

4. Reduced serum HDL cholesterol: Less than

5. Elevated fasting blood glucose: Equal to or greater than $100 \mathrm{mg} / \mathrm{dl}$ or use of medication for hyperglycemia.

Their mean age was $49.00 \pm 0.91$ years, and their mean BMI was $35.35 \pm 0.58 \mathrm{~kg} / \mathrm{m}^{2}$.

Group (2) Ten women none of them fulfilled the three standardized criteria, they were considered as control group. Their mean age was $43.80 \pm 2.04$ years and their mean BMI was $34.08 \pm 2.02 \mathrm{~kg} / \mathrm{m}^{2}$.

The study lasted for 8 weeks, divided into two equal periods of four weeks each. During the first period, they followed a low caloric balanced diet that was designed to supply $900-1000 \mathrm{~K}$ calories/ day, containing $24 \%$ proteins, $45 \%$ carbohydrates and $31 \%$ fats mostly unsaturated. During the second period, they continued on the same low caloric diet with replacement of Baladi bread by the cookies in breakfast and dinner to supply nearly the same calories (3 cookies/day).

All the included females were subjected to the following: Full medical history, clinical examination, and anthropometric measurements. Blood pressure was measured with participants sitting quietly for 5 minutes using a mercury sphygmomanometer. Mean of the three readings were recorded.

\section{Anthropometric measurements}

Anthropometric measurements were recorded with the subjects dressed in light clothing. Height and weight were evaluated following the standard method of Jelliffe, 1966 [21], and were used to calculate body mass index $(\mathrm{BMI})=$ weight in $\mathrm{kg} / \mathrm{square}$ height in meters $(\mathrm{kg} /$ m2) [22]. Waist circumference (WC) was measured at the narrowest point superior to the hip using a flexible light metal tape (minimal waist). All measurements were taken by the same researcher to assure accuracy.

\section{Blood sampling}

Fasting blood samples (14 hours) were drawn from all subjects before regimen, after 4 weeks and lastly at the end of 8 weeks. $2 \mathrm{ml}$ of Blood samples were collected on EDTA tubes for detection of glycated hemoglobin $(\mathrm{HbA} 1 \mathrm{C})$ in the fresh whole blood. The rest of the blood samples were collected on plain tubes, left to clot and then centrifuged at $3000 \mathrm{rpm}$ for 10 minutes and the sera were separated. Fasting blood glucose was determined on fresh sera; the remaining sera were stored at $-70 \mathrm{C}^{\circ}$ until used for determination of other biochemical parameters.

\section{Biochemical analysis}

Quantitative colorimetric determination of Glycated haemoglobin (HbA1c) was performed by cation exchange resin. Stanbio-Laboratory no.102181Ce, USA [23]. Blood glucose was determined using oxide peroxidase method [24]. Serum total cholesterol, HDLC and triglycerides were done using: cholesterol proceed No 1010 [25], Stanbio, HDL-C proceed No 0599 [26] and stanbio Liquicolor triglycerides proceed No 2100 [27] respectively. Friedewald formula was used to calculate LDL-C; LDL-C = (Total Cholesterol) $-(\mathrm{HDL}-\mathrm{C})-(\mathrm{TG} / 5)$ [28].

Oxidized LDL (ox-LDL) was determined using ox-LDL/MDA adduct Elisa Kit. Immundiagnostik AG, Stubenwald-Allee 8a, D 64625 Bensheim (Germany) [29]. Serum insulin was measured using Insulin AccuBind ELISA Microwells, Product Code: 2425-300. Monobind, INC, Costa Mesa, CA 92627 (USA) [30].

Homeostatic model assessment-insulin resistance (HOMA-IR) was calculated using the following equation: HOMA-IR=Fasting insulin $\left(\mathrm{XN}_{\mathrm{N}} / \mathrm{ml}\right) \times$ Fasting glucose $(\mathrm{mg} / \mathrm{dl}) / 405$ [31].

\section{Statistical analysis}

This is a case-control study. The study was designed to compare results and data between obese cases and controls, and to find the correlation between different included variables. Statistical analysis was performed using SPSS software (SPSS Inc., Chicago, IL, version 17.0, 2008). Data are expressed as means \pm SE. Independent-samples $t$ tests compared the data between cases and controls. Pearson's correlation coefficient $(r)$ was calculated to find correlations between different variables. $P$ value is considered significant at $<$ 0.05 .

\section{Results}

Table 1 shows the macronutrients, the tannins and some of the minerals contents of the formula used in the dietary therapy (/100g of its dry weight). The tested baked sample is characterized by its high content of protein, carbohydrate $(9.8 \& 53.9 \%$ of its dry weight 
Table 1: Composition of tested baked sample (/100g dry weight).

\begin{tabular}{lc}
\hline Composition & Amount \\
\hline Total Protein $(\mathrm{g})$ & 9.8 \\
Total Fat $(\mathrm{g})$ & 26.3 \\
Carbohydrate $(\mathrm{g})$ & 53.7 \\
Dietary fiber $(\mathrm{g})$ & 10.2 \\
Tannins $(\mathrm{mg})$ & 1.095 \\
Fe $(\mathrm{mg})$ & 58.1 \\
$\mathrm{Na}(\mathrm{mg})$ & 2280.3 \\
$\mathrm{~K}(\mathrm{mg})$ & 5380.3 \\
Ca $(\mathrm{mg})$ & 1891.3 \\
\hline
\end{tabular}

respectively), polyphenol compounds and potassium.

Figure 1 shows the percent of the fatty acids content of the formula used in the dietary therapy. It is

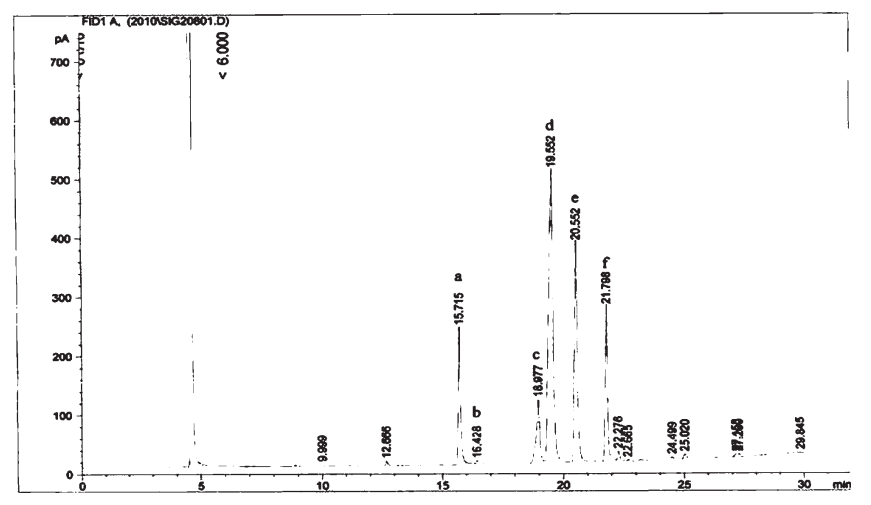

Figure 1: Relative area percentage of fatty acids contents of tested formula. a: Palmetic (C16:0) 10.69\%, b:Palmeto-oleic (C16:1) 0.19\%, c: Stearic (C18:0) 7.70\%, d: Oleic (C18:1) 43.96\%, e: Linoleic (C18:2) 21.73\% and f:Linolenic (C18:3) 12.70\%.

characterized by its low content of saturated fatty acids (Palmetic and Stearic acids), and its high content of unsaturated fatty acids: oleic acid (43.69\% of total fatty acids) and the omega-3 fatty acids, linoleic and linolenic fatty acids ((21.73\% and $12.70 \%$ respectively).
Table 2 shows the mean characteristic anthropometric and biochemical parameters of the whole studied sample at three visits during the dietary therapy. The results showed that all the anthropometric

Table 2: Anthropometric and biochemical parameters of the studied sample at the different periods of the dietary therapy.

\begin{tabular}{|c|c|c|c|}
\hline Parameters & Base (1 $1^{\text {sl }}$ visit) & Mid (2n visit) & Last $\left(3^{\text {rd }}\right.$ visit) \\
\hline Age (year) & $47.76 \pm 0.90$ & & \\
\hline Height $(\mathrm{cm})$ & $158.14 \pm 0.95$ & & \\
\hline Weight $(\mathrm{Kg})$ & $87.91 \pm 2.14$ & $86.10 \pm 2.00^{* * a}$ & $84.91 \pm 1.94^{\star \star b}$ \\
\hline $\mathrm{BMI}\left(\mathrm{Kg} / \mathrm{m}^{2}\right)$ & $35.05 \pm 0.65$ & $34.33 \pm 0.59^{* * a}$ & $33.86 \pm 0.57^{\star \star b}$ \\
\hline Waist (cm) & $93.64 \pm 1.18$ & $90.86 \pm 1.06^{* * a}$ & $88.05 \pm 0.96^{* \star 0}$ \\
\hline 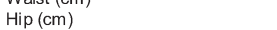 & $119.49 \pm 1.48$ & $116.56 \pm 1.40^{* \star \mathrm{a}}$ & $114.49 \pm 1.40^{\star \star b}$ \\
\hline$W H R(\mathrm{~cm} / \mathrm{cm})$ & $0.79 \pm 0.008$ & $0.78 \pm 0.008$ & $0.77 \pm 0.007^{* * !}$ \\
\hline $\mathrm{SBP}(\mathrm{mmHg})$ & $131.29 \pm 3.0$ & $122.52 \pm 2.83^{* *^{a}}$ & $117.71 \pm 2.52^{\star^{\mathrm{b}}}$ \\
\hline $\begin{array}{l}\mathrm{SBP}(\mathrm{mm} \mathrm{mg}) \\
\mathrm{DBP}(\mathrm{mm} \mathrm{Hg})\end{array}$ & $\begin{aligned} 131.29 & \pm 3.0 \\
83.57 & \pm 1.32\end{aligned}$ & $\begin{aligned} 122.52 \pm 2.83 \\
82.00 \pm 1.20\end{aligned}$ & $\begin{aligned} 1111.11 & \pm 2.52^{*} \\
78.14 & \pm 0.95^{* \star b}\end{aligned}$ \\
\hline T. cholesterol (mg/dl) & $226.33 \pm 6.75$ & $197.94 \pm 5.27^{\star \star^{\mathrm{a}}}$ & $176.42 \pm 4.51^{\star \star^{b}}$ \\
\hline LDL-C $(\mathrm{mg} / \mathrm{dl})$ & $138.89 \pm 7.43$ & $107.09 \pm 6.20^{* * a}$ & $83.37 \pm 4.88^{\star \star b}$ \\
\hline HDL-C (mg/dl) & $50.12 \pm 1.87$ & $61.51 \pm 1.98^{* * \mathrm{a}}$ & $66.28 \pm 2.02^{\star \star b}$ \\
\hline Non HDL-C (mg/dl) & $176.21 \pm 7.94$ & $138.43 \pm 6.39^{\star \star a}$ & $110.15 \pm 5.21^{\star \star b}$ \\
\hline Risk factor ( $\mathrm{T}$.cholesterol/ HDL-C) & $4.94 \pm 0.32$ & $3.42 \pm 0.18^{\star * a}$ & $2.78 \pm 0.12^{\star \star b}$ \\
\hline Triglycerides (mg/dl) & $186.60 \pm 7.40$ & $146.70 \pm 6.52^{* * a}$ & $133.89 \pm 8.19^{* \star b}$ \\
\hline $\begin{array}{l}\text { VLDL-C (mg/dll) } \\
\text { VIdlat }\end{array}$ & $37.32 \pm 1.48$ & $29.34 \pm 1.30^{* * a}$ & $26.78 \pm 1.63^{* \star 5}$ \\
\hline Ox-LDL (mg/mal) & $\begin{array}{l}31.32 \pm 1.48 \\
148.89 \pm 14.87\end{array}$ & $\begin{array}{l}29.34 \pm 1.30 \\
118.11 \pm 10.65^{* \mathrm{a}}\end{array}$ & $\begin{array}{l}20.18 \pm 1.63 \\
96.02 \pm 7.22^{\star \star 0}\end{array}$ \\
\hline $\begin{array}{l}\text { Ox-LDL (ng/ml) } \\
\text { FBG (mg/dl) }\end{array}$ & $\begin{array}{l}148.89 \pm 14.8 \mathrm{r} \\
116.15 \pm 5.59\end{array}$ & $\begin{array}{r}118.11 \pm 10.65 \\
99.87 \pm 3.98^{* * a}\end{array}$ & $\begin{array}{l}96.02 \pm 7.22^{* \star 6} \\
91.69 \pm 2.71^{* * 0}\end{array}$ \\
\hline $\mathrm{HbA} \mathrm{A}_{1}(\%)$ & $6.25 \pm 0.16$ & $5.61 \pm 0.82^{* * a}$ & $5.39 \pm 0.10^{* b}$ \\
\hline Insulin $(\mu \mathrm{IU} / \mathrm{ml})$ & $8.71 \pm 0.73$ & $6.41 \pm 0.45^{\star \star a}$ & $6.12 \pm 0.54$ \\
\hline HOMA-IR & $2.62 \pm 0.28$ & $1.59 \pm 0.13^{\star \star \mathrm{a}}$ & $1.38 \pm 0.13$ \\
\hline
\end{tabular}

parameters and the blood pressure decreased significantly $(p<0.05-0.01)$ after the two periods of the dietary therapy. The higher decreases of the WHR and the DBP were detected after the end of the second period when the supplement was added.

The ox-LDL and the components of the lipid profile decreased significantly at $p<0.01$ after the two periods of therapy, except HDL-C which increased significantly. FBG and $\mathrm{HbA} 1 \mathrm{c}$ decreased significantly at $p<0.05 \& 0.01$ after the end of the two periods. Insulin and HOMA-IR decreased significantly by the end of the first period and decreased only numerically by the end of the second period.

Table 3 represents the metabolic syndrome criteria as Mean \pm SE for cases and controls at the different periods of dietary therapy. Comparing the two groups, significant differences were found between them at the three visits regarding all the criteria $(p<0.05 \&$

Table 3: Comparison of Metabolic syndrome criteria among the two studied groups at the different periods of dietary therapy.

\begin{tabular}{|c|c|c|c|c|c|c|}
\hline \multirow{2}{*}{ Parameters } & \multicolumn{3}{|c|}{$\begin{array}{l}\text { Obese without MetS (Control) } \\
\text { (Group 1: n. 10) }\end{array}$} & \multicolumn{3}{|c|}{$\begin{array}{l}\text { Obese with MetS } \\
\text { (Group 2: n. 32) }\end{array}$} \\
\hline & Base ( $1^{\text {st }}$ visit $)$ & $\operatorname{Mid}\left(2^{\text {nd }}\right.$ visit $)$ & Last (3 $3^{\text {rd }}$ visit) & Base $\left(1^{\text {st }}\right.$ visit $)$ & $\operatorname{Mid}\left(2^{\text {nd }}\right.$ vis it $)$ & Last ( $3^{\text {rd }}$ visit) \\
\hline $\begin{array}{l}\text { Waist }(\mathrm{cm}) \\
\text { SBP }(\mathrm{mmHg}) \\
\operatorname{DBP}(\mathrm{mmHg})\end{array}$ & $\begin{aligned} 89.00 & \pm 1.75 \\
120.80 & \pm 2.18 \\
77.00 & \pm 1.33\end{aligned}$ & $\begin{array}{r}88.02 \pm 1.50 \\
113.00 \pm 3.89 \\
77.40 \pm 1.86\end{array}$ & $\begin{array}{r}85.00 \pm 1.97 \\
105.00 \pm 3.94 \\
74.00 \pm 1.25\end{array}$ & $\begin{aligned} 95.09 & \pm 1.36^{* a} \\
134.56 & \pm 3.71^{* a} \\
85.62 & \pm 1.52^{* * a}\end{aligned}$ & $\begin{array}{c}91.75 \pm 1.28 \\
125.50 \pm 3.37 \\
83.44 \pm 1.37^{\star \mathrm{b}}\end{array}$ & $\begin{aligned} 89.00 & \pm 1.06 \\
121.69 & \pm 2.73^{* * \mathrm{c}} \\
79.44 & \pm 1.09^{* \mathrm{c}}\end{aligned}$ \\
\hline $\begin{array}{l}\text { HDL-C (mg/dl) } \\
\text { Triglyc erides }(\mathrm{mg} / \mathrm{dl})\end{array}$ & $\begin{array}{c}60.17 \pm 2.49 \\
137.94 \pm 11.00\end{array}$ & $\begin{array}{r}72.98 \pm 1.44 \\
108.44 \pm 9.20\end{array}$ & $\begin{array}{l}77.54 \pm 2.17 \\
97.86 \pm 12.48\end{array}$ & $\begin{array}{r}46.98 \pm 2.04^{* * a} \\
201.81 \pm 7.27^{* * a}\end{array}$ & $\begin{array}{r}57.92 \pm 2.21^{* \star b} \\
158.66 \pm 6.84^{* \star b}\end{array}$ & $\begin{array}{r}62.76 \pm 2.24^{\star * c} \\
145.15 \pm 9.22^{* c}\end{array}$ \\
\hline $\mathrm{FBG}(\mathrm{mg} / \mathrm{dl})$ & $92.37 \pm 4.02$ & $75.48 \pm 2.52$ & $76.29 \pm 1.91$ & $123.58 \pm 6.73^{* a}$ & $107.49 \pm 4.37^{* \star b}$ & $96.50 \pm 3.05^{* *} \mathrm{C}$ \\
\hline
\end{tabular}

Values are mean \pm SE. a: Base obese vs. base MetS; b: Mid obese vs. Mid MetS; c: Last obese vs. Last MetS; ${ }^{*}<0.05 ;{ }^{*} \mathrm{P}<0.01$ 
Moaty et al. Oxidized Low Density Lipoprotein and Non-High Density Lipoprotein Cholesterol in Metabolic Syndrome

Table 4: Comparison of Anthropometric and biochemical parameters among the two studied groups at the different periods of dietary therapy.

\begin{tabular}{|c|c|c|c|c|c|c|}
\hline \multirow{2}{*}{ Parameters } & \multicolumn{3}{|c|}{$\begin{array}{l}\text { Obese without MetS } \\
\text { (Group 1: n. 10) }\end{array}$} & \multicolumn{3}{|c|}{$\begin{array}{l}\text { Obese with MetS } \\
\text { (Group 2: n. 32) }\end{array}$} \\
\hline & Base ( $1^{\text {st }}$ visit $)$ & Mid ( $2^{\text {nd }}$ visit $)$ & Last ( $3^{\text {rd }}$ visit) & Base $\left(1^{\text {st }}\right.$ visit $)$ & Mid (2 ${ }^{\text {nd }}$ visit) & Last ( $3^{\text {rd }}$ vis it) \\
\hline Age (year) & $43.80 \pm 2.04$ & & & $49.00 \pm 0.91^{* a}$ & & \\
\hline Height (cm) & $162.00 \pm 1.54$ & & & $156.93 \pm 1.08^{* a}$ & & \\
\hline Weight (Kg) & $89.80 \pm 6.18$ & $89.20 \pm 5.67$ & $88.25 \pm 5.63$ & $87.31 \pm 2.11$ & $85.13 \pm 1.99$ & $83.56 \pm 1.86$ \\
\hline $\operatorname{BMI}\left(\mathrm{Kg} / \mathrm{m}^{2}\right)$ & $34.09 \pm 2.02$ & $33.87 \pm 1.82$ & $33.51 \pm 1.82$ & $35.35 \pm 0.58$ & $34.47 \pm 0.55$ & $33.97 \pm 0.51$ \\
\hline Hip $(\mathrm{cm})$ & $120.70 \pm 4.11$ & $117.64 \pm 3.56$ & $115.66 \pm 3.80$ & $119.11 \pm 1.50$ & $116.22 \pm 1.49$ & $114.12 \pm 1.44$ \\
\hline WHR $(\mathrm{cm} / \mathrm{cm})$ & $0.74 \pm 0.02$ & $0.75 \pm 0.02$ & $0.74 \pm 0.01$ & $0.80 \pm 0.01^{* a}$ & $0.79 \pm 0.01^{* \mathrm{~b}}$ & $0.78 \pm 0.01^{* * c}$ \\
\hline T. cholesterol (mg/dl) & $188.20 \pm 9.81$ & $179.31 \pm 10.13$ & $155.09 \pm 7.07$ & $238.00 \pm 7.15^{\star \star a}$ & $203.76 \pm 5.85^{\star \mathrm{b}}$ & $183.09 \pm 4.98^{* \star c}$ \\
\hline LDL-C (mg/dl) & $100.44 \pm 10.77$ & $84.65 \pm 10.87$ & $57.98 \pm 6.75$ & $150.90 \pm 8.11^{* * a}$ & $114.10 \pm 7.04^{* \mathrm{~b}}$ & $91.30 \pm 5.35^{\star * c}$ \\
\hline Non HDL-C (mg/dl) & $128.03 \pm 10.00$ & $106.33 \pm 9.60$ & $77.55 \pm 8.32$ & $191.26 \pm 8.34^{* * a}$ & $145.84 \pm 7.11^{* * b}$ & $120.33 \pm 5.17^{* * c}$ \\
\hline Risk factor (T.cholesterol/ HDL-C) & $3.18 \pm 0.22$ & $2.46 \pm 0.13$ & $2.02 \pm 0.13$ & $5.50 \pm 0.37^{* \star a}$ & $3.73 \pm 0.21^{* * \mathrm{~b}}$ & $3.02 \pm 0.13^{* * c}$ \\
\hline VLDL-C (mg/dl) & $27.59 \pm 2.19$ & $21.69 \pm 1.84$ & $19.57 \pm 2.50$ & $40.36 \pm 1.45^{\star \star a}$ & $31.73 \pm 1.37^{* \star b}$ & $29.03 \pm 1.85^{* \mathrm{c}}$ \\
\hline Ox-LDL (ng/ml) & $94.72 \pm 48.40$ & $77.95 \pm 6.75$ & $67.00 \pm 7.85$ & $165.82 \pm 18.39^{\star a}$ & $130.66 \pm 13.09^{\star b}$ & $105.08 \pm 8.59^{\star c}$ \\
\hline $\mathrm{HbA}_{1} \mathrm{C}(\%)$ & $5.57 \pm 0.19$ & $4.69 \pm 0.12$ & $4.90 \pm 0.17$ & $6.46 \pm 0.18^{* a}$ & $5.90 \pm 0.12^{* \star b}$ & $5.55 \pm 0.10^{\star \star c}$ \\
\hline Insulin $(\mu \mathrm{lU} / \mathrm{ml})$ & $8.68 \pm 1.92$ & $7.52 \pm 1.47$ & $7.08 \pm 1.32$ & $8.73 \pm 0.73$ & $6.07 \pm 0.37$ & $5.82 \pm 0.58$ \\
\hline HOMA-IR & $1.99 \pm 0.43$ & $1.48 \pm 0.35$ & $1.31 \pm 0.23$ & $2.81 \pm 0.34$ & $1.62 \pm 0.13$ & $1.40 \pm 0.15$ \\
\hline
\end{tabular}

Values are mean \pm SE. a: Base obese vs. base Met s; b: Mid obese vs Mid Met s; c: Last obese vs. Last Met s; ${ }^{*}<0.05 ;{ }^{* *} \mathrm{P}<0.01$.

0.01), except waist circumference and SBP which showed significant difference between the two groups at the basal visit only, and at the basal and last visits respectively.

Table 4 shows mean \pm SE of the other anthropometric and biochemical parameters among the obese control subjects and the metabolic syndrome patients at the different periods of dietary therapy. MetS patients were older and shorter. No significant differences were found between the anthropometric parameters, except WHR at the three visits. Lipid profile and ox-LDL showed significant differences between the two groups during all visits at $p<0.05-0.01$. Regarding HbA1c, a significant difference was observed between the two groups all over the study and was more prominent at the mid and last visits $(p<0.01)$. The levels of insulin and HOMA-IR decreased in both groups but with no significant difference.

Table 5 represents the correlations between different variables and both of non-HDL-C and ox-LDL among metabolic syndrome patients. A high significant negative correlation was found between HDL- $C$ and non HDL-C at the basal and mid visits only, while a high significant positive correlation was observed between the later and the waist circumference at the basal visit only. Also a significant difference is seen regarding oxLDL and both of insulin concentration all over the period of the study, and DBP at the last visit only.

\section{Discussion}

MetS is characterized by an increase in the total body fatness and preferential upper body accumulation of fat that tend to develop more insulin resistance, hyperinsulinemia, glucose-intolerance and dyslipidemia than obese women with greater proportion of lower body fat [32].

According to the International Diabetes Federation [20], 76.2\% of the investigated obese women in our study proved to be MetS patients. Our data showed that the MetS patients were significantly older,

Table 5: Pearson's Correlations between each of Non HDL-C and ox-LDL, and the criteria of the MetS among the MetS patients at the different periods of dietary therapy.

\begin{tabular}{|c|c|c|c|c|c|c|}
\hline \multirow{3}{*}{ Parameters } & \multicolumn{3}{|c|}{ Non HDL-C (mg/dl) } & \multicolumn{3}{|c|}{ Ox-LDL (ng/ml) } \\
\hline & \multicolumn{6}{|c|}{ Obese with Met S (Group 2: n. 32) } \\
\hline & $\begin{array}{c}\text { Base } \\
\left(1^{\text {st }} \text { visit }\right)\end{array}$ & $\begin{array}{c}\text { Mid } \\
\text { (2nd visit) }\end{array}$ & $\begin{array}{c}\text { Last } \\
\left.\text { ( } 3^{\text {rd }} \text { visit }\right)\end{array}$ & $\begin{array}{c}\text { Base } \\
\left(1^{\text {st }} \text { visit }\right)\end{array}$ & $\begin{array}{c}\text { Mid } \\
\left(2^{\text {nd }} \text { visit }\right)\end{array}$ & $\begin{array}{c}\text { Last } \\
\left(3^{\text {rd }} \text { visit }\right)\end{array}$ \\
\hline Waist (cm) & $.428^{*}$ & -.017 & .128 & .019 & .151 & .035 \\
\hline $\begin{array}{l}\mathrm{FBG}(\mathrm{mg} / \mathrm{dl}) \\
\mathrm{HbA} \mathrm{C}(\%)\end{array}$ & $\begin{array}{l}.110 \\
-.008\end{array}$ & $\begin{array}{l}-.173 \\
-.202\end{array}$ & $\begin{array}{l}-.032 \\
-.122\end{array}$ & $\begin{array}{l}-.235 \\
-.196\end{array}$ & $\begin{array}{l}-.172 \\
-.182\end{array}$ & $\begin{array}{l}-.040 \\
.159\end{array}$ \\
\hline HDL-C (mg/dl) & $-.661^{* *}$ & $-.676^{\star *}$ & -.301 & -.156 & -.041 & -.080 \\
\hline $\mathrm{SBP}(\mathrm{mmHg})$ & .247 & -.061 & .044 & .021 & .214 & .299 \\
\hline $\mathrm{DBP}(\mathrm{mmHg})$ & .239 & .080 & -.025 & .255 & .286 & $.461^{* *}$ \\
\hline Triglycerides (mg/dl) & .246 & .151 & .081 & .322 & -.010 & .224 \\
\hline Insulin $(\mu \mathrm{IU} / \mathrm{ml})$ & -.055 & -.244 & .026 & $.570^{\star *}$ & $.468^{* *}$ & $.856^{* *}$ \\
\hline
\end{tabular}

Numbers presented in this table are the value of $r=$ correlation coefficient. ${ }^{*}$ Correlation is significant at the 0.05 level (2-tailed); ${ }^{* \star}$ Correlation is significant at the 0.01 level (2-tailed). 
shorter, had higher mean waist circumference, waist to hip ratio and disturbed lipid profile, compared to the obese women not suffering from MetS. In addition the mean concentrations of the FBG and $\mathrm{HbA} 1 \mathrm{C}$, insulin and HOMA-IR values were higher.

Atherogenic dyslipidemia which is one of the most important component of MetS is associated with increased risk of cardiovascular disease [8]. Accordingly, two approaches had been used in this study to investigate the abnormality in the lipid profiles among both obese and MetS patients, by determining ox-LDL-C, a marker of lipoprotein-associated oxidative stress, and non HDLC, and their response after using the two different dietary methods.

Our data are in agreement with the previous observation which reported that circulating ox-LDL is associated with obesity, and that weight loss results in decreased ox-LDL level [33]. Fat taken from visceral compartment, in comparison with subcutaneous tissue fat is a metabolically active organ [34], composed of large insulin resistant adipocytes has a well-developed vasculature with infiltration of inflammatory cells [35]. In this study decreased waist circumference and WHR were associated with a decrease in the mean level of oxLDL in both the investigated groups. Protection of LDL oxidation by nut intake has been documented in some but not all clinical studies [36].It has been reported that every dietary plant contains numerous types of antioxidants with different properties. A diet rich in fruits, vegetables, minimal refined cereals and nuts is associated with lower risk of degenerative diseases. Since oxidative stress is common in chronic degenerative diseases, it has been assumed that dietary antioxidants may explain this protective effect [37].

Ox-LDL showed positive association with the different criteria of the MetS. Significant correlations were observed between ox-LDL levels and insulin concentrations all over the studied periods, and with the diastolic blood pressure at the end of the supplementation period. A study reported that hyperinsulinemia and impaired glycaemic control independent of lipid level were associated with increased in vivo LDL oxidation, as reflected by the higher prevalence of highly oxidized LDL [5]. Ox-LDL is reported to interfere with the homeostasis of adipose tissue by altering the normal balance between differentiation and proliferation in preadipocyte, which potentially contributes to the appearance of insulin resistance [38].

Our results showed that LDL-C concentrations were within the normal range in both groups, yet its level was higher among Mets patients. It has been stated that metabolic syndrome patients with overt type 2 diabetes, non-HDL-C may be stronger predictor of CVD than LDLC or TG because it correlates highly with atherogenic lipoproteins. Target goal for LDL-C and non-HDL-C in patients are below $100 \mathrm{mg} / \mathrm{dl}$, and below $130 \mathrm{mg} / \mathrm{dl}$ respectively. Failure to consider the importance of nonHDL-C in patients may result in under treatment of them [39]. In this study our MetS patients successfully reached these desired levels mainly after the daily supplement containing $\mathrm{H} \approx 24 \mathrm{~g} /$ day tigernut. In a systemic review, it was concluded from randomized controlled intervention trials that consumption of 50-100 g (approximately 1.53.5 servings) of nuts five or more times/ week as a part of heart healthy diet with a total fat content (high in MUFA and/ or PUFA) of approximately $35 \% \mathrm{E}$. may significantly decrease total cholesterol and LDL-C [40].

The positive significant correlation between nonHDL and the waist circumference only at the beginning of the study, adds weight to the known role played by the visceral obesity in the promotion of the atherogenic status among MetS patients. It is well known that low levels of HDL-C are associated with an increased risk of CVD independent of LDL-C, and raising HDL-C has been shown to significantly lower cardiovascular risk. Non HDL-C represents the cholesterol concentration of atherogenic lipoprotein (VLDL, IDL and LDL-C). The Negative significant correlation between the non HDL-C and HDL-C in our study, pointed to the risky effect of this negative association among the MetS patients at the beginning of the study, yet it was pointed to the beneficial effect of the dietary therapy in the other two periods. One potential mechanism that might mediate the decrease in the level of the atherogenic non HDL-C was the high fiber content of the dietary supplement used in this study. Tigernut contains a relative high level of fiber (21.3\%) for the seeds [41], while wheat is characterized by high insoluble fiber [42]. In addition, tigernut was found to be rich in oleic (MUFA) and linoleic (PUFA) fatty acids [43]. Chemical results of our supplement revealed that it contains $43.9 \%$ and $21.73 \%$ of its oil content as oleic and linoleic acids respectively. MUFA in the diet has two important effects; decreasing in LDL-C and maintaining the HDL-C at a higher level. Furthermore, LDL-C particles rich in oleate have been shown to be less susceptible to oxidation (44). However, the decreased risk of cardiovascular disease and metabolic syndrome associated with nut consumption is not solely related to fatty acid profile, but may be due in part to the presence of other bioactive components (arginine, fiber, copper 
and magnesium). In addition, they also supply significant amounts of tocopherols, squalene and phytosterol that are relevant compounds with antioxidant properties [45].

In conclusion, our findings proved that the metabolic syndrome in obese Egyptian women was associated with increased atherogenic dyslipidemia. The dietary therapy combining hypocaloric regimen, and the supplement composed of tigernut and whole wheat, proved to be effective in the management of obese and MetS patients. Reduction of body weight, waist circumference and others metabolic syndrome factors were associated with a reduction of oxidized LDL and non HDL-C. The current data warrant further investigations into the role of lifestyle and nutritional interventions that inhibit tissue-associated oxidation of LDL in the prevention of the metabolic syndrome.

\section{References}

1. Kahn R, Buse J, Ferrannini E, Stern M. The metabolic syndrome: time for a critical appraisal: joint statement from the American Diabetes Association and the European Association for the Study of Diabetes. Diabetes Care. 2005; 28(9): 2289-2304.

2. Stern MP, Williams K, Hunt KJL. Impact of diabetes/metabolic syndrome in patients with established cardiovascular disease. Atheroscler Suppl. 2005; 6(2): 3-6.

3. Esposito K, Ciotola M, Giugliano D. Oxidative stress in metabolic syndrome. J Endocrinol Invest. 2006; 29: 791-795.

4. Cipolletta C, Ryan KE, Hanna EV, Trimble ER. Activation of peripheral blood CD14+ monocytes occurs in diabetes. Diabetes. 2005;54(9):2779-2786.

5. Holvoet P. Relation between metabolic syndrome, oxidative stress and inflammation and cardiovascular disease. Verh $\mathrm{K}$ Acad Geneeskd Belg. 2008; 70(3):193-219.

6. Furukawa S, Fujita T, Shimabukuro M. Increased oxidative stress in obesity and its impact on metabolic syndrome. J Clin Invest. 2004; 114(12): 1752-1761.

7. Third report of National cholesterol Education program (NCEP) Expert Panel on Detection, Evaluations, and Treatment of High Blood Cholesterol in Adults (Adult Treatment Panel III) Final Report. Circulation. 2002; 106: 3143-3221.

8. Wagner AM,Perez A, Zapico E, Ordonezuanos J. Non-H DL cholesterol and apolipoprotein $B$ in the dyslipidemic classification of type 2 diabetic patients. Diabetes Care. 2003; 26: 2048-2051.

9. Pischon T, Girman GJ, Sacks FM, Rifai N, Stampfer NJ, Rimm EB. Non -high density lipoprotein cholesterol and Apolipoprotein $B$ in the prediction of coronary heart disease in men. Circulation. 2005;112:3375-3383.

10. Patel C, Ghanim H, RanishankarS, Sia CL, Viswanathan P, Mohantym P, Dandona P. Prolonged reactive oxygen species generation and Nuclear Factor- KB activation after a high fat, high carbohydrate meal in the obese. J Clin Endocrinol Metab. 2007;92:4476-4479.

11. Fernandez-Sanchez A, Madrigal- Santillan E, Bautista M, Esquivel- Soto J, Morales- Gonzalez A, Esquirel Soto J, Morales- Ganzalez A, Equivel- Chirino C, Durante-Montiel I, Sanchez - Riverra G, Valadez-Vega C, Morales-Gonzalez- JA. Inflammation oxidative stress, and obesity. Int J Mol Sci. 2011; 12: 3117-3132.

12. Flight I, Clifton P. Cereal grains and legumes in the prevention of coronary heart disease and stroke: a review of the literature. Eur J Clin Nutr. 2006;60:1145-1159.

13. Kris-Etherton PM, Hu FB, Ros E, Sabate J. The role of tree nuts and peanuts in the prevention of coronary heart disease: multiple potential mechanism. J Nutr. 2008; 138:51746-1751.

14. David AB. Tigernut . A Dictionary of Food and Nutrition. 2005. Encyclopedia.com:http://www.encyclopedia.com/doc/ 1039-tigernut.html. Accessed May, 2010.

15. A.O.A.C. (Association of official analytical Chemists) Official Methods of Analysis of official Analytical Chemists., 2 Vols 15th ed Washington DC. 1990; 70, 668, 931, 933 and 937.

16. A.O.A.C. (Official Method of Analysis of the Association of Official Agriculture Chemists) 16th ed Volume II, Section 45.4.07, Methods, 985.29.1997.

17. Soylak M, Tuzen M, Narin I, Sari H. Comparison of microwave, dry and wet digestion procedures for determination of trace metal contents in spice samples produced in Turkey. J Food Drug Anal. 2004;12(3): 254-258.

18. A.O.A.C. Official Methods of Analysis of the Association of Official Agricultural Chemists, 17th ed, Published by A.O.A.C., 2000.

19. Adekanmi OK, Oluwatooyin OF, Yemisi OA, Yemisi AA. Influence of processing techniques on the nutrient and antinutrient of tiger nut (Cyperus Esculentus L.). W J of Dairy \& Food Science. 2009;4(2):88-93.

20. The International Diabetes Federation (IDF) consensus worldwide definition of the metabolic syndrome. http;// www.idf.org/webdata/docs/IDF.Metabolic syndrome definition. PDF (accessed March 5, 2010).

21. Jelliffe DB. The assessment of the nutritional status of the community. World Health Organization, Geneva Monograph. 1966; 35:63-69.

22. Center for Disease Control and prevention (CDC) about BMI for adults, 2006. 
23. Abraham EC, Huff' TA, Cope ND. Determination of the glycosylated hemoglobin (HbA1) with a new micro-column procedure. Diabetes. 1978;27:931-937.

24. Barham D, Trinder P. An improved color reagent for determination of blood glucose by oxidase system. Analyst. 1972; 97:142-145.

25. Allain CC, Poon LS, Chan CS, Richmond W, Fu PC Enzymatic determination of total serum cholesterol. Clin Chemo. 1974;20:470- 475.

26. Wornick DF, Albers JJ. A comprehensive evaluation of the heparin-manganese precipitation procedure for estimating high density lipoprotein cholesterol. J Lipid Res.1978;19:65-76.

27. Seidel J, Klos S, Ziegenhorn T. AACC Meeting Abstract 34. Clin Chem. 1993;39:1127.

28. Friedewald WI, Levy RI, Fredrickson DS. Estimation of the concentration of low density lipoprotein cholesterol in plasma, without use of the preparative ultracentrifuge. Clin Chem.1972; 18:499-502.

29. Corsi MM, Dogliotti G, Pedroni F, Ermetici F, Malavazos A, Ambrosi B. ADMA: A possible role in obese patients. Poster P173 of the 6th World Congress on Hyperhomocysteinemia, Saabrucken, Germany, June 5-9, erschienen in CCLM 45(5). 2007.

30. Temple RC, Clark PM, Hales CN. Measurement of insulin secretion in type 2 diabetes: problems and pitfalls. Diabetic Medicine. 1992;9:503-512.

31. Mattews DR, Hosker JP, Rudenski AS, Naylor BA, Treacher DF, Turner RC. Homeostasis model assessment, insulin resistance and beta-cell function from fasting plasma glucose and insulin concentration in man. Diabetologia.1985;28:412419.

32. Gupta A, Gupta V. Metabolic syndrome: what are the risks for humans? Bio Science Trends. 2010;4:204-212.

33. Weinbrenner T, Schroder H, Escurriol V, Fito M, Elosua R, Vila J, Marruqat J, Covas MI. Circulating oxidized LDL is associated with increased waist circumference independent of body mass index in men and women. Am J Clin Nutr. 2006;83: 30-35.
34. Wajchenberg BL. Subcutaneous and visceral adipose tissue: their relation to the metabolic syndrome. Endocr Rev. 2000;21:697-738.

35. Durnjak L, Durnjak M. The metabolic syndrome-an ongoing story. J Physiol Pharmacol. 2009;60(Suppl 7):19-24.

36. Ros E. Nuts and novel biochemical markers of Cardiovascular disease. Am J Clin Nutr. 2009;89:1649S16565 S.

37. Biomhoff R, Carlsen MH, Anderson LF, Jacobs DR Jr. Health benefit of nuts: potential role of antioxidant. $\mathrm{Br} \mathrm{J}$ Nutr. Suppl. 2006; 2:S 52- 60.

38. D’Archivio M, Scazzocchio B, Filesic, Vari R, Maggiorella MT, Semicola L, Santangelo C, Giovannini C, Masella R. Oxidised LDL up-regulate CD36 Expression by the Nrf2 pathway in 3T3-L1 preadipocytes . FEBS Lett. 2008; 582: 22912298.

39. Peters AL. Clinical prevalence of non-HDL- cholesterol in patients with diabetes. Clin Diabetes. 2008; 26: 3-7.

40. Mukuddem-Peterson J, Oosthuizen W,Jerling JCJ. Asystemic review of the effects of nuts on blood lipid profiles in human. J Nutr. 2005; 135: 2082-2089.

41. Zhang HY, Hanna MN, Yusuf A, Nan L. Yellow nut-sedge (Cyperus Esculentus) tuber oil as a fuel. Industrial Crop and product. 1990; 5:177-187.

42. Harris KA, Kriss-Etherton PM. Effect of whole grains on coronary heart disease risk. Curr Atheroscler Rep. 2010;12:368-376.

43. Eteshola E, Oraedu ACI. Fatty acid composition of tigernut tubers (Cyperus Esculentus), baobab seeds (Adasonia digitata L.) and their mixture. J Am Oil Chem Soc. 1996;73:255-257.

44. Fito M, Dela Torre R, Covas MI. Olive oil and oxidative stress. Mol Nutr Food Res. 2007;51:1215-1224.

45. Ros E, Cabre-Vila JJ, Salas-Salvado J. Effects of one serving of mixed nuts on serum lipids, insulin resistance and inflammatory markers in patients with metabolic syndrome. Nutr Metab Cardiovasc Dis. 2011;21:126-135. 